\title{
Functional expression in Escherichia coli of proteins $B$ and $C$ from soluble methane monooxygenase of Methylococcus capsulatus (Bath)
}

\author{
Charlotte A. West, George P. C. Salmond, Howard Dalton and J. Colin Murrell* \\ Department of Biological Sciences, University of Warwick, Coventry, CV4 7AL, UK
}

(Received 17 February 1992; revised 10 April 1992; accepted 14 April 1992)

\begin{abstract}
Methylococcus capsulatus (Bath) uses a soluble methane monooxygenase (sMMO) to catalyse the oxidation of methane to methanol. sMMO is comprised of three components; A, B and C. Protein C (the reductase) transfers electrons from NADH to protein A (the hydroxylase) which contains the active site, and protein $B$ regulates this electron flow. The five genes encoding the sMMO proteins and their subunits are clustered and have been cloned in Escherichia coli. A DNA fragment containing mmoB, the gene encoding protein B, was subcloned into pT7-5, a plasmid of the T7 RNA polymerase promoter expression system. Upon induction, $E$. coli expressed protein B which was fully functional after purification. The gene encoding protein $\mathrm{C}, \mathrm{mmoC}$, was amplified with unique restriction sites at each end using the polymerase chain reaction and then subcloned into pT7-7 (a plasmid similar to pT7-5 but containing its own ribosome-binding site and ATG start codon). Protein C expressed in $E$. coli was also found to be functional. This is the first report of the functional expression of methanotroph methane monooxygenase genes in a heterologous host and represents a significant step forward in our analysis of the assembly and catalysis of sMMO.
\end{abstract}

\section{Introduction}

Methylococcus capsulatus (Bath) is a type X obligate methanotroph which derives its carbon and energy solely from methane. Methane is converted to methanol and subsequently to formaldehyde, which can be assimilated into cellular biomass or further oxidized to $\mathrm{CO}_{2}$ to provide reducing power for biosynthesis. The conversion of methane to methanol is catalysed by methane monooxygenase (MMO), a non-specific enzyme complex which can also catalyse the oxidation of a wide range of aliphatic, alicyclic and aromatic compounds (Colby et al., 1977; Higgins et al., 1979). The wide substrate range of MMO has attracted much commercial interest due to its potential for use in important biotransformations such as the production of propylene oxide (Lidstrom \& Stirling, 1990).

$M$. capsulatus (Bath) possesses two MMOs, one membrane-bound (pMMO) and the other soluble (sMMO). sMMO activity is inhibited by copper ions and is expressed only when the copper to biomass ratio is low, while pMMO is present in growth conditions where copper ions are abundant (Stanley et al., 1983; Dalton

* Author for correspondence. Tel. (0203) 523523; fax (0203) 523701.

Abbreviation: sMMO, soluble methane monooxygenase. et al., 1984; Prior \& Dalton, 1985). The regulation of sMMO and pMMO, and the involvement of copper in the switch, is not yet understood, and indeed it appears that only Methylococcus and Methylosinus species possess sMMO (Anthony, 1986).

Extensive characterization of the sMMO complex by DEAE-cellulose chromatography has resolved three components, A, B and C, all of which are required for enzyme activity (Colby \& Dalton, 1978; Woodland \& Dalton, 1984; Green \& Dalton, 1986). Protein A $(210 \mathrm{kDa})$ is made up of two copies each of the three subunits $\alpha(54 \mathrm{kDa}), \beta(44 \mathrm{kDa})$ and $\gamma(20 \mathrm{kDa})$. It is a non-haem iron protein which contains an unusual $\mu$-hydroxo bridge structure believed to be the active site (Ericson et al., 1988). The single-subunit protein B $(16 \mathrm{kDa})$ contains no prosthetic groups and is thought to regulate electron transfer (Green \& Dalton, 1985; Liu \& Lippard, 1991). Protein B always co-purifies with a truncated form $\mathrm{B}^{\prime}$, which is approximately $1 \mathrm{kDa}$ smaller (Pilkington et al., 1990). These two protein forms have as yet eluded resolution. Protein $\mathrm{C}(38 \mathrm{kDa})$ is an ironsulphur flavoprotein which is responsible for the transfer of electrons from NADH to protein A (Lund \& Dalton, 1985; Lund et al., 1985).

The detailed purification and characterization of sMMO from M. capsulatus (Bath) gave biochemical data 
which were used to allow the genetic isolation of the sMMO genes. Oligonucleotide probes complementary to the $\mathrm{N}$-terminal amino acid sequences of the structural proteins enabled the cloning of the $\gamma$ subunit gene (Mullens \& Dalton, 1987), the $\beta$ subunit gene (Stainthorpe et al., 1989) and finally the whole gene cluster (Stainthorpe et al., 1990). All five genes were found to be linked on a $7 \mathrm{~kb}$ DNA fragment with an ORF of unknown function located between the genes encoding the $\gamma$ subunit of protein A and protein C. Another ORF was subsequently characterized as the gene encoding protein B (Pilkington et al., 1990). Protein homology searches revealed that the $\alpha$ subunit of protein $A$ possesses conserved regions which show homology to ribonucleotide reductase B2 protein, and both proteins contain the same type of binuclear iron centre (Sjöberg $e t$ al., 1987; Stainthorpe et al., 1990). Protein C was found to be significantly homologous at the $\mathrm{N}$ terminus with ferredoxins from plants, cyanobacteria and archaebacteria (Takahashi et al., 1983; Hase et al., 1978, 1982). There are also homologies with NADH-cytochrome $b_{5}$ reductase from human erythrocytes which, like protein $\mathrm{C}$, contains $1 \mathrm{~mol}$ FAD (mol protein) ${ }^{-1}$ and accepts reducing equivalents from NADH.

To fully understand the enzymic action of sMMO it is necessary to identify the amino acid residues that are directly involved in the binding of iron within the $\mu$-hydroxo bridge, and to determine whether they are essential for sMMO activity. It is also necessary to elucidate the manner in which methane, and indeed the other hydrocarbons bind and are oxidized by sMMO, and finally the way in which the components within the enzyme complex interact with each other. To accomplish this, the individual structural genes need to be functionally expressed in $E$. coli so that site-directed mutagenesis can be used to determine, for example, the role of individual amino acid ligands in the hydroxylation process.

We report here for the first time the expression of methane monooxygenase proteins in a heterologous host. Proteins B and C have been expressed in $E$. coli using a T7 RNA polymerase promoter (Tabor, 1990) and the recombinant proteins were found to be fully functional in reconstitution experiments.

\section{Methods}

Growth conditions. $E$. coli cells were grown at $37^{\circ} \mathrm{C}$ in aerated LuriaBertani broth or on Luria-Bertani agar $(1.5 \%, \mathrm{w} / \mathrm{v})$ (Maniatis et al., 1982), except strain K 38 containing pGP1-2 which was grown at $30^{\circ} \mathrm{C}$. Growth of cells for subsequent induction of recombinant proteins was carried out on enriched medium (Tabor, 1990). Growth of $M$. capsulatus (Bath) and preparation of cell-free extracts containing sMMO were carried out according to the method of Colby \& Dalton (1978). The antibiotics ampicillin and kanamycin were prepared in water and filter-sterilized before addition to media at a final concentration of $75 \mu \mathrm{g} \mathrm{ml}^{-1}$.

Plasmid DNA isolation. Preparation of plasmid DNA (both small and large scale) was by alkaline lysis (Maniatis et al., 1982). The Gene Clean II Kit (BI0101, Stratech Scientific) was used to isolate DNA from agarose and to purify it further before ligation. All routine DNA manipulations, such as restriction endonuclease digestions, phosphatasing and ligations were carried out by the methods of Maniatis et al. (1982). Conditions for the use of DNA manipulation enzymes were those recommended by suppliers.

Electroporation. DNA was electroporated into bacterial cells using a Bio-Rad Gene Pulser and Pulse Controller at $200 \mathrm{Ohms}$ and $25 \mu \mathrm{F}$.

SDS-PAGE and Western blotting. SDS-PAGE was carried out on $12 \%(\mathrm{w} / \mathrm{v})$ acrylamide gels (Laemmli, 1970) stained with Coomassie Brilliant Blue. The Western blotting procedure (Towbin et al., 1979) used a Gradipore electroblotting system and Hybond $\mathrm{C}$ nitrocellulose (Amersham). Antibodies were raised to the individual $M$. capsulatus (Bath) proteins in rabbits using 0.5 to $1 \mathrm{mg}$ purified protein resuspended in Freund's adjuvant (Harlow \& Lane, 1988).

Polymerase chain reaction $(P C R)$. Primers were synthesized on an Applied Biosystems DNA synthesizer and purified by HPLC. PCR was carried out on a Hybaid Combi Thermal Reactor TR2 using the Perkin Elmer Cetus Gene Amp PCR reagent kit.

$T 7$ RNA polymerase/promoter system. Strains and plasmids were kindly supplied by $\mathrm{S}$. Tabor, Department of Biological Chemistry and Molecular Pharmacology, Harvard Medical School, Boston, MA, USA. Expression using the two plasmid system and selective labelling of plasmid-encoded proteins were carried out as described by Tabor (1990).

Protein purification. Soluble cell-free extract was resolved into fractions $\mathrm{A}, \mathrm{B}$ and $\mathrm{C}$ by ion exchange chromatography on a DEAEcellulose column. Further purification was carried out on Mono $Q$ ion exchange columns (Woodland \& Dalton, 1984; Colby \& Dalton, 1978; Pilkington et al., 1990).

MMO assay. MMO activity was determined by measuring the oxidation of propene to epoxypropane by cell-free extracts and purified MMO components (Colby \& Dalton, 1978). Activities are reported in nmol propylene produced $\min ^{-1}(\mathrm{mg} \text { protein })^{-1}$.

\section{Results}

Expression of protein B in E. coli

pCH4 DNA (Stainthorpe et al., 1990) was isolated from $E$. coli $\mathrm{DH} 1$ and digested with the restriction endonuclease PstI. The resulting DNA fragments were separated using agarose gel electrophoresis and the $1.7 \mathrm{~kb}$ fragment, containing $m m o B$, the $3^{\prime}$ end of $m m o Y$ and the majority of $m m o Z$, was isolated and purified. This fragment was then ligated to pT7-5, which had been cut with PstI and treated with alkaline phosphatase to prevent its recircularization and the resulting construct, pEB51, was electroporated into E. coli DH1 (Fig. 1). pEB51, was then electroporated into $E$. coli K 38 pGP1-2 and the plasmid-encoded proteins selectively labelled with $\left[{ }^{35}\right.$ S $]$ methionine. The resulting autoradiogram (Fig. 2) shows a protein product of the expected size for protein $\mathrm{B}(16 \mathrm{kDa})$ and one of approximately $24 \mathrm{kDa}$ 


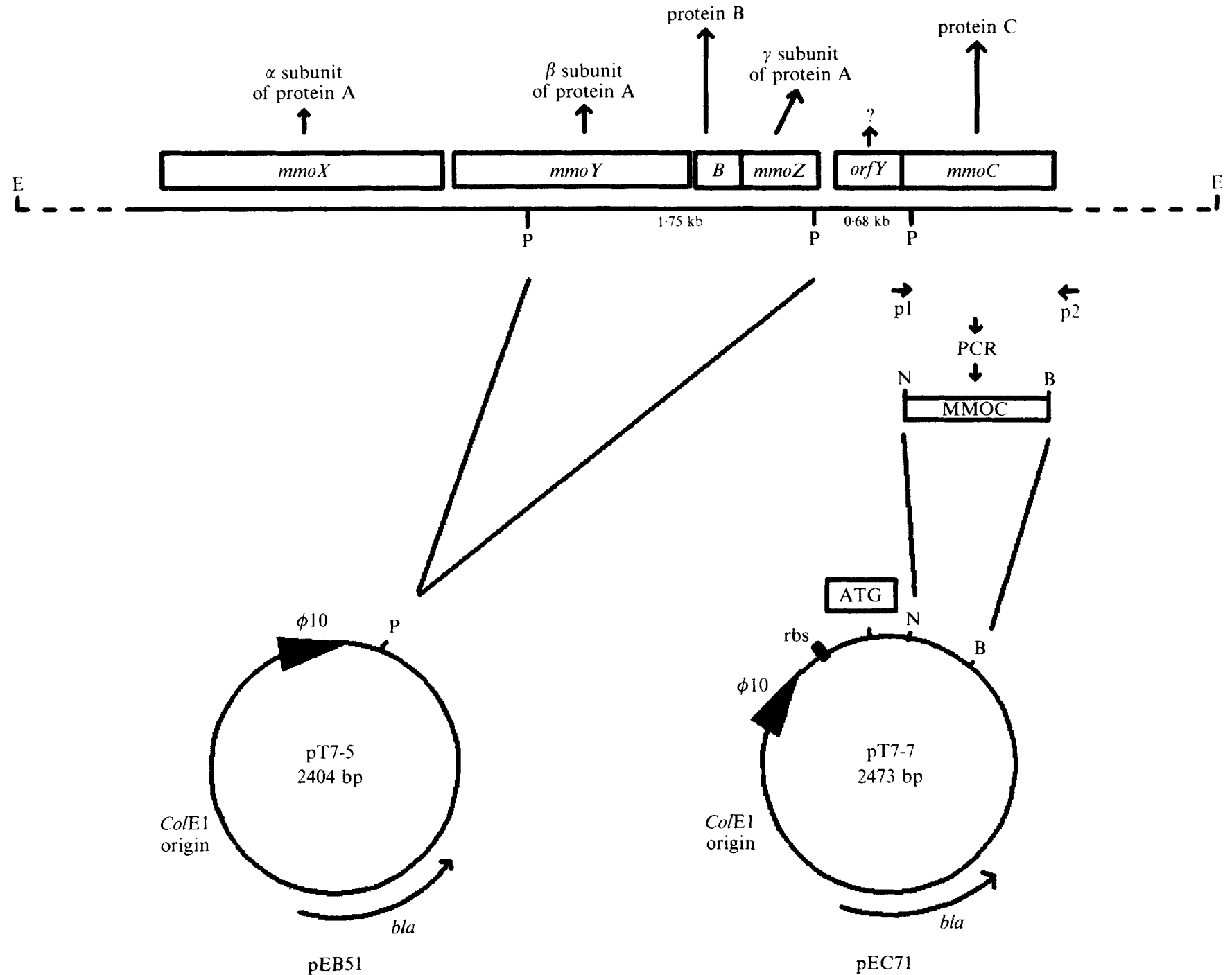

Fig. 1. Construction of expression plasmids. The EcoRI fragment from pCH4 containing the methane monooxygenase gene cluster of $M$. capsulatus (Bath) was used in the subcloning of $m m o B$ and $m m o C$ [and also orf $Y$ ] to construct the expression plasmids pEB51 and pEC71 as described in Results. E, EcoRI; P, PstI; N, NdeI ; B, BamHI; rbs, ribosome binding site; $\phi 10$, T7 RNA polymerase promoter.

which is thought to be an expressed protein resulting from read-through from the $\gamma$ subunit of protein A into pT7-5. The natural terminators of $m m o Z$ are not present on the $1.7 \mathrm{~kb}$ PstI fragment, and pT7-5 contains no artificial terminators after the polylinker.

Soluble cell-free extracts of heat-induced E. coli $\mathrm{K} 38$ pEB51 pGP1-2 were then analysed by SDS-PAGE and an additional band was seen at $16 \mathrm{kDa}$ (Fig. 3). A control of $E$. coli $\mathrm{K} 38$ pT7-5 pGP1-2 did not produce the same protein product. This band was identified as protein $\mathrm{B}$ by its co-migration with purified protein $\mathrm{B}$ from $M$. capsulatus (Bath) (data not shown) and, via Western blotting, by its interaction with antibody raised to protein B from $M$. capsulatus (Bath) (Fig. 3). Using the expression system approximately $2 \%$ of the soluble cellfree extract was protein $B$.
Reconstitution of SMMO activity using recombinant protein $B$ expressed in $E$. coli

Soluble cell-free extracts of $E$. coli K38 pEB51 pGP1-2 were assayed for MMO activity in combination with purified proteins A and C from $M$. capsulatus (Bath). When assaying proteins $A$ and $C$ in the absence of protein B, no epoxypropane was produced; however, upon addition of the $E$. coli soluble cell-free extract containing recombinant protein $\mathrm{B}$, functional activity was achieved. Upon addition of the control $E$. coli $\mathrm{K} 38$ pT7-5 pGP1-2, no activity was seen, showing that $E$. coli does not possess a protein functionally interchangeable with protein $\mathbf{B}$.

Purified recombinant protein B (Fig. 3), assayed in reconstitution experiments, gave a specific activity of 


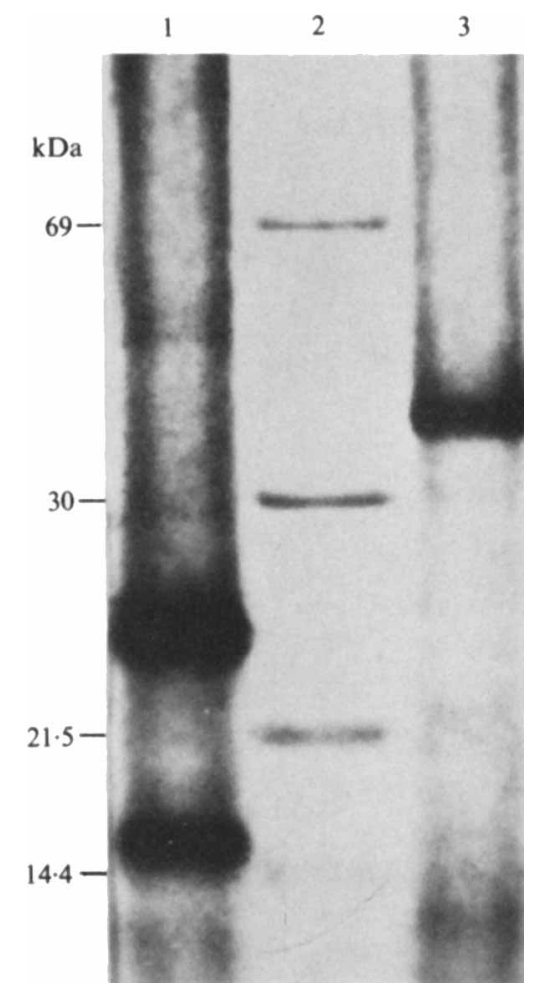

Fig. 2. Autoradiogram of plasmid-encoded proteins, produced solely from the T7 RNA polymerase promoter, labelled with $\left[{ }^{35} \mathrm{~S}\right]$ methionine. Lanes: 1, E. coli K38 pEB51 pGP1-2; 2, labelled protein standards; 3, E. coli $\mathrm{K} 38$ pEC71 pGP1-2.
$8200 \mathrm{nmol} \mathrm{min}{ }^{-1}$ (mg protein) $)^{-1}$, which is comparable to protein B purified from $M$. capsulatus (Bath).

E. coli K38 pEB51 pGP1-2, like $M$. capsulatus (Bath), produced both B and B' (Pilkington et al., 1990) the latter being seen as a faint band below the majority protein $\mathrm{B}$ band in gels stained with Coomassie Blue, and in Western blots.

\section{Expression of protein $C$ in E. coli}

Owing to the lack of suitable restriction endonuclease sites within $\mathrm{pCH} 4$, the protein $\mathrm{C}$ gene $m m o C$ was subcloned using the polymerase chain reaction (PCR) technique. mmoC from $M$. trichosporium OB3b (Cardy et $a l ., 1991)$ had previously been sub-cloned into pT7-6 and was found to be expressed only at very low levels (data not shown). This was thought to be due to poor translational initiation and therefore pT7-7 was chosen to express $M$. capsulatus protein C since it has an integral ribosome-binding site and an ATG start codon with the correct spacing and base composition for efficient translation.

A pair of primers was designed to create a PCR product of $m m o C$ with a Bam $\mathrm{HI}$ site at the $3^{\prime}$ end and a NdeI site spanning the ATG start codon (Fig. 4). In this way, digestion with $N d e I$ and subsequent insertion into

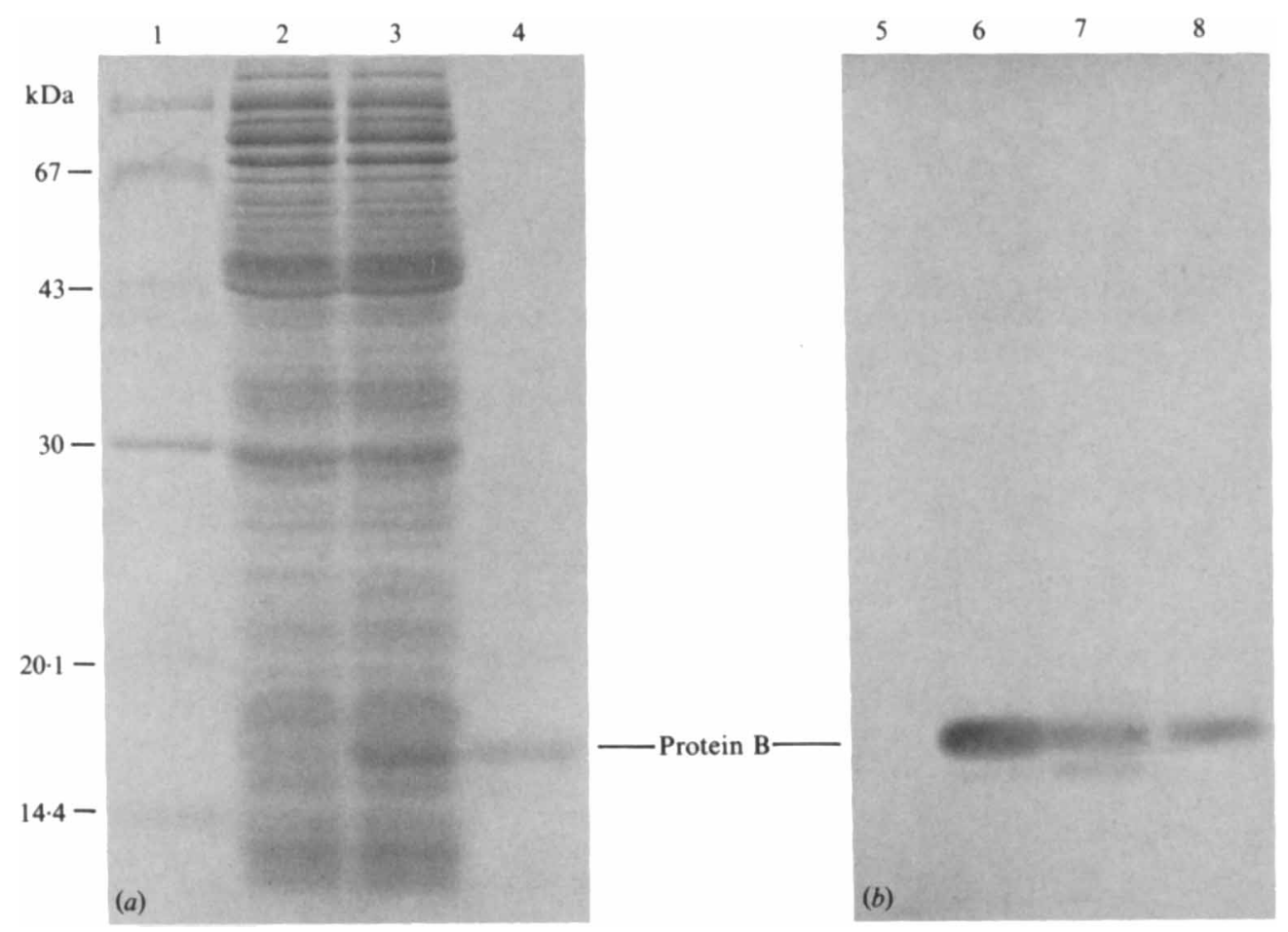

Fig. 3. Expression of protein B. (a) Coomassie-stained polyacrylamide gel of soluble cell-free extracts, induced as described by Tabor (1990), and purified protein B. (b) Western blot of soluble cell-free extracts and purified protein with antibody raised against purified protein B from $M$. capsulatus (Bath). Lanes: 1, protein standards; 2, E. coli K38 pT7-5 pGP1-2; 3, E. coli K 38 pEB51 pGP1-2; 4, purified protein B from E. coli K38 pEB51 pGP1-2; 5, as lane 2; 6, as lane 3; 7, as lane 4; 8, M. capsulatus (Bath). 
(a)

Start codon 5' --- ATGCAGCGAGTTCACACTATCACGGC-----

$3^{\prime}-$ - TACGTCGCTCAAGTGTGATAGTGCCG-.---

$5^{\prime}$ GGCATATGCAGCGAGTTCACACTATC 3 NdeI pl-->

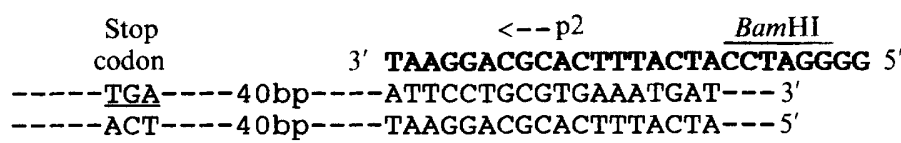

(b)

$$
5^{\prime}-\frac{\text { TAATACGACTCACTATAGGGAGA }}{\text { T7 promoter }}-43 \text { bp-- } \frac{\text { AAGGAGATATACATATG }}{\text { rbs }}-3^{\prime}
$$

Fig. 4. The use of PCR and the translation expression vector pT7-7 in the construction of pEC71. (a) Primers pl and p2. p1 was designed to be homologous with the start of $m m o C$ and to contain a $5^{\prime}$ NdeI site spanning the start codon. p2 was designed to be homologous with a region downstream of the end of $m m o C$ and to terminate with a BamHI restriction endonuclease site. The resulting PCR product comprises the complete $m m o C$ flanked by $N d e$ I and $B a m H I$ restriction sites. GG 'caps' are present 5 ' to both the $N d e I$ and $B a m H I$ restriction sites, as these allow efficient digestion of the PCR product with these endonucleases. (b) The T7 promoter region, ribosome binding site and $N d e$ I restriction site of pT7-7. The mmoC PCR product was cloned into the NdeI site thus positioning it exactly for efficient translation.
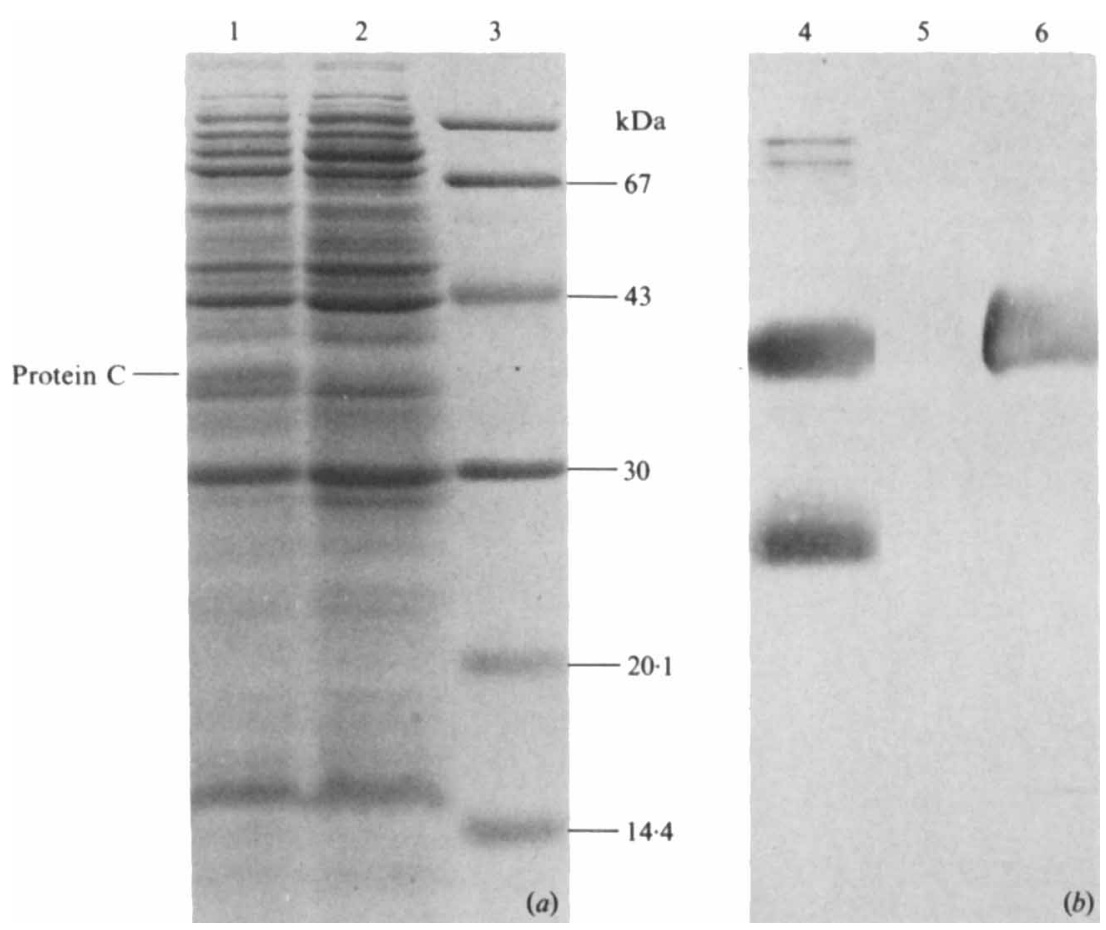

Fig. 5. Expression of protein C. (a) Coomassie-stained polyacrylamide gel of soluble cell-free extracts, induced as described by Tabor (1990). (b) Western blot of soluble cell-free extracts and purified protein with antibody raised against purified protein $C$ from $\boldsymbol{M}$. capsulatus (Bath). Lanes: 1, E. coli K38 pEC71 pGP1-2; 2, E. coli K38 pT7-7 pGP1-2; 3, protein standards; 4, as lane 1; 5, as lane 2;6, purified protein $\mathrm{C}$ from $\boldsymbol{M}$. capsulatus (Bath). 
pT7-7 would place the $m m o C$ gene appropriately for efficient translation. This was carried out to form the construct pEC71 (Fig. 1) which was then electroporated into $E$. coli $\mathrm{K} 38$ pGP1-2. Selective labelling of plasmidencoded proteins with ${ }^{35} \mathrm{~S}$-methionine resulted in a labelled polypeptide of the expected size for protein $\mathrm{C}$ (Fig. 2). Analysis of cell-free extracts prepared from heat-induced $E$. coli $\mathrm{K} 38$ pEC71 pGP1-2 by SDS-PAGE also showed an additional band of approximately $38 \mathrm{kDa}$, which in Western blotting experiments was seen to cross-react with antibody raised to purified protein $\mathrm{C}$ from $M$. capsulatus (Bath) (Fig. 5). This antibody was also seen to cross-react with a protein band of approximately $24 \mathrm{kDa}$, however, since the antibody is polyclonal this probably represents non-specific binding to a protein product from the plasmid $\mathrm{pEC} 71$. Production of protein $\mathrm{C}$ by the expression system is approximately $2 \%$ of the soluble cell-free extract.

\section{Reconstitution of SMMO activity using recombinant protein $C$ expressed in $E$. coli}

Soluble cell-free extracts of E. coli K38 pEC71 pGP1-2 were assayed for $\mathrm{MMO}$ activity in combination with purified proteins A and B from $M$. capsulatus. Recombinant protein $\mathrm{C}$ was found to be functional, with a specific activity of $88 \mathrm{nmol} \mathrm{m^{-1 }}(\mathrm{mg} \text { protein })^{-1}$. The control E. coli K38 pT7-7 pGP1-2 did not restore functional activity to the purified $\mathrm{A}$ and $\mathrm{B}$ components from $M$. capsulatus. Epoxypropane assays were also carried out on purified protein A from $M$. capsulatus (Bath) combined with recombinant proteins B and C. Functional activity was found (data not shown).

\section{Expression of the protein encoded by orf $Y$}

To express the protein encoded by orf $Y$ in $E$. coli, the same strategy as for protein B was used except that the 685 bp PstI fragment from pCH4 (Fig. 1) was subcloned into pT7-5. Upon selective $\left[{ }^{35}\right.$ S $]$ methionine-labelling of the plasmid-encoded proteins, a faint band at $12 \mathrm{kDa}$ could be seen (data not shown) however expression was too low for the protein product to be visualized using SDS-PAGE.

\section{Discussion}

In this communication, we report on the functional expression of two components of $M$. capsulatus (Bath) sMMO in a heterologous host, $E$. coli. Recombinant protein B was purified and found to be fully functional, and although recombinant protein $C$ was not purified, its

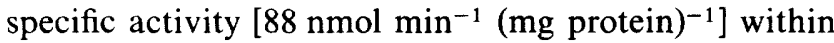

the soluble cell-free extract is comparable to that of $M$. capsulatus protein $\mathrm{C}\left[70 \mathrm{nmol} \mathrm{min}^{-1}(\mathrm{mg} \text { protein })^{-1}\right]$ at the same stage of purification (Colby \& Dalton, 1978). These advances constitute a major breakthrough in methanotroph molecular biology since they open the way to further structure/function studies and site-directed mutagenesis experiments on this complex enzyme. Protein B is a simple protein with no prosthetic groups and therefore its functional expression is not greatly surprising. Protein $\mathrm{C}$ contains both flavin and an ironsulphur centre and it is therefore more remarkable that correct assembly occurred in E. coli. E. coli, however, possesses an $\mathrm{Fe}_{2} \mathrm{~S}_{2}$-type ferredoxin and other ironsulphur enzymes, for example, sulphur reductase and formate dehydrogenase (Yoch \& Carithers, 1979) and our results indicate that it is also able to assemble ironsulphur centres in foreign proteins such as protein $C$. Both proteins $\mathrm{B}$ and $\mathrm{C}$ consist of single polypeptides; however, protein $A$ is comprised of dimers of three different polypeptides and whether $E$. coli will be able to assemble this more complex protein is currently under investigation.

Although expression of proteins $B$ and $C$ was relatively low, at approximately $2 \%$ of the soluble cell-free extract, it is reasonable to assume that considerable improvements can be made, for example by the modification of the induction procedure, by the insertion of strong terminators downstream of the inserted genes or by the use of $l$ lon $^{-}$expression strains. Expression could also be improved by the use of the pET vectors (Goeddel, 1990) which are essentially the same at those used here, but have several additional features such as the inclusion of the R1.1 RNAase III cleavage site downstream of the cloning site. This system also includes the use of plasmids (pLysE and pLysS) which contain the T7 lysozyme gene; this gene increases the stability of plasmids containing inserted DNA to be expressed. Once expression levels have been increased, correspondingly larger amounts of proteins $\mathrm{B}$ and $\mathrm{C}$ will be available for biochemical analysis. As in M. capsulatus (Bath), E. coli soluble cellfree extracts and purified protein $B$ were found to contain $\mathbf{B}$ and $\mathbf{B}^{\prime}$. In the former, very little of the $\mathbf{B}^{\prime}$ form was evident, but upon purification, its level increased (Fig. 3). Both of these proteins are known to have the same $\mathrm{N}$-terminal sequence and limited proteolysis of protein B with trypsin induces the appearance of $\mathrm{B}^{\prime}$ and loss of activity (Pilkington et al., 1990). It is thought that $\mathrm{B}^{\prime}$ is a specific breakdown product of $\mathrm{B}$ with the modification probably occurring at the C-terminal end, suggesting a functional role for this region. It is not known whether this proteolysis is a means by which protein $B$ activity is regulated, but the fact that the same process occurs in $E$. coli indicates that it is not under the specific control of the $M$. capsulatus chromosome, and 
any regulation (if indeed it is this and not merely a fortuitous occurrence) must lie entirely within the conformation of protein $\mathbf{B}$ alone.

The function of $\operatorname{orf} Y$ is as yet unknown and the protein product has not been isolated from $M$. capsulatus (Bath). The expressed protein product is now available from $E$. coli and will be used in epoxypropane assays of sMMO to ascertain whether the orf $Y$ product has any effect on in vitro sMMO activity.

This work was funded by Gas Research Institute, 8600 West Bryn Mawr Avenue, Chicago, Illinois 60631. Contract No. 5089-260-1826.

\section{References}

ANThony, C. (1986). Bacterial oxidation of methane and methanol. Advances in Microbial Physiology 27, 113-210.

Cardy, D. L. N., Laidler, V., Salmond, G. P. C. \& Murrell, J. C. (1991). Molecular analysis of the methane monooxygenase (MMO) gene cluster of Methylosinus trichosporium OB3b. Molecular Microbiology 5, 335-342.

Colby, J. \& Dalton, H. (1978). Resolution of the methane monooxygenase of Methylococcus capsulatus (Bath) into three components. Biochemical Journal 171, 461-468.

Colby, J., Stirling, D. \& Dalton, H. (1977). The soluble methane monooxygenase of Methylococcus capsulatus (Bath). Its ability to oxygenate $n$-alkanes, $n$-alkenes, ethers, alicyclic aromatic and heterocyclic compounds. Biochemical Journal 165, 395-403.

Dalton, H., Prior, S. D., Leak, D. J. \& Stanley, S. (1984). Regulation and control of methane monooxygenase. In Microbial growth on $C_{1}$ compounds, pp. 75-82. Edited by R. L. Crawford \& R. S. Hanson. Proceedings of the 4th International Symposium. Washington DC: American Society for Microbiology.

Ericson, A., Hedman, B., Hodgson, K. O., Green, J., Dalton, H., Bentsen, J. G., BeER, R. H. \& Lippard, S. J. (1988). Structural characterization by EXAFS spectroscopy of the binuclear iron centre in protein A of methane monooxygenase from Methylococcus capsulatus (Bath). Journal of the American Chemical Society 110, 2330-2332.

GoEdDEL, D. V. (1990). Gene expression technology. Methods in Enzymology 185, 60-89.

Green, J. \& Dalton, H. (1985). Protein B of the soluble methane monooxygenase of Methylococcus capsulatus (Bath): a novel regulatory protein of enzyme activity. Journal of Biological Chemistry 260, 15795-15801.

GreEn, J. \& Dalton, H. (1986). Steady-state kinetic analysis of soluble methane monooxygenase from Methylococcus capsulatus (Bath). Biochemical Journal 236, 155-162.

Harlow, E. \& Lane, D. (1988). Antibodies. A Laboratory Manual. Cold Spring Harbor, NY: Cold Spring Harbor Laboratory Press.

Hase, T., Wakabayashi, S., Matsubara, H., Kerscher, L., Oesterhelt, D., RaO, K. K. \& Hall, D. O. (1978). Complete amino acid sequence of Halobacterium halobium ferredoxin containing an $\mathrm{N}^{\mathrm{E}}$ acetyllysine residue. Journal of Biochemistry 83, 1657-1670.

Hase, T., Matsubara, H., Hutber, G. N. \& Rogers, L. J. (1982). Amino acid sequences of Nostoc strain MAC ferredoxins I and II. Journal of Biochemistry 92, 1347-1355.

Higgins, I. J., Hammond, R. C., Sariaslani, F. S., Best, D., Davies, M. M., TRYHORN, S. E. \& TAYLOR, F. (1979). Biotransformation of hydrocarbons and related compounds by whole organism suspensions of methane-grown Methylosinus trichosporium OB3b. Biochemical and Biophysical Research Communications 89, 671-677.

LAEMMLI, U. K. (1970). Cleavage of structural proteins during the assembly of the head of the bacteriophage T4. Nature 227, 680-685.

Lidstrom, M. E. \& Stirling, D. I. (1990). Methylotrophs: genetics and commercial applications. Annual Reviews of Microbiology 44, $27-58$.

LIU, K. E. \& LiPPARD, S. J. (1991). Redox properties of the hydroxylase component of methane monooxygenase from Methylococcus capsulatus (Bath). Journal of Biological Chemistry 266, 12836-12839.

Lund, J. \& Dalton, H. (1985). Further characterization of the FAD and $\mathrm{Fe}_{2} \mathrm{~S}_{2}$ redox centres of component $\mathrm{C}$, the $\mathrm{NADH}$ : acceptor reductase of the soluble methane monooxygenase of Methylococcus capsulatus (Bath). European Journal of Biochemistry 147, 291-296.

Lund, J., Woodland, M. P. \& Dalton, H. (1985). Electron transfer reactions in the soluble methane monooxygenase of Methylococcus capsulatus (Bath). European Journal of Biochemistry 147, 297-305.

Maniatis, T., Fritsch, E. F. \& Sambrook, J. (1982). Molecular Cloning: a Laboratory Manual. Cold Spring Harbor, NY: Cold Spring Harbor Laboratory Press.

Mullens, I. A. \& Dalton, H. (1987). Cloning of the gamma-subunit methane monooxygenase from Methylococcus capsulatus. Biotechno$\log y 5,490-493$.

Pilkington, S. J., Salmond, G. P. C., Murrell, J. C. \& Dalton, H. (1990). Identification of the gene encoding the regulatory protein $B$ of soluble methane monooxygenase. FEMS Microbiology Letters 72 , 345-348.

Prior, S. D. \& Dalton, H. (1985). The effect of copper ions on membrane content and methane monooxygenase activity in methanol-grown cells of Methylococcus capsulatus (Bath). Journal of General Microbiology 131, 155-163.

Sjöberg, B. M., SANders-Loehr, J. \& Loehr, T. M. (1987). Identification of a hydroxide ligand at the iron centre of ribonucleotide reductase by resonance raman spectroscopy. Biochemistry 26, $4242-4247$.

Stainthorpe, A. C., Murrell, J. C., Salmond, G. P. C., Dalton, H. \& LEES, V. (1989). Molecular analysis of methane monooxygenase from Methylococcus capsulatus (Bath). Archives of Microbiology 152, 154-159.

Stainthorpe, A. C., Lees, V., Salmond, G. P. C., Dalton, H. \& MurRell, J. C. (1990). The methane monooxygenase gene cluster of Methylococcus capsulatus (Bath). Gene 91, 27-34.

Stanley, S. H., Prior, S. D. Leak, D. J. \& Dalton, H. (1983). Copper stress underlies the fundamental change in intracellular location of methane monooxygenase in methane-oxidizing organisms: studies in batch and continuous cultures. Biotechnology Letters 5, 487-492.

TABOR, S. (1990). Expression using the T7 RNA polymerase/promoter system. In Current Protocols in Molecular Biology. pp. 16.2.1-16.2.11. Edited by F. A. Ausubel, R. Brent, R. E. Kingston, D. D. Moore, J. G. Seidman, J. A. Smith \& K. Struhl. New York: Greene Publishing and Wiley-Interscience.

Takahashi, Y., Hase, T., Wada, K. \& Matsubara, H. (1983). Ferrodoxins in developing spinach cotyledons; the presence of two molecular species. Plant Cell Physiology 24, 189-198.

Towbin, H., Staehelin, T. \& Gordon, J. (1979). Electrophoretic transfer of proteins from polyacrylamide gels to nitrocellulose sheets: procedure and some applications. Proceedings of the National Academy of Sciences of the United States of America 76, 4350-4354.

WoOdland, M. P. \& Dalton, H. (1984). Purification and properties of component $\mathrm{A}$ of the methane monooxygenase from Methylococcus capsulatus (Bath). Journal of Biological Chemistry 259, 53-59.

YoCH, D. C. \& Carithers, R. P. (1979). Bacterial iron-sulphur proteins. Microbiology Reviews 43, 384-421. 